\title{
The Concept of New Women in the Short Stories of Odia Writer Binapani Mohanty
}

\author{
Chinmayee Nanda \\ Asst Professor \\ KIIT Deemed to be University, Bhubaneswar \\ Research Scholar \\ Sambalpur University \\ Odisha, India \\ chinmayeenanda2013@gmail.com
}

\begin{abstract}
I deliberate on examining few of the liberated women or the New Women presented in an Odia short story writer Binapani Mohanty's stories. In her stories, the persona and disposition is finding a place for constructive thrive, but again those are not really allowed to flourish in a full fledged manner. With the change of time and different dynamics of the modern scenario, women have started to become aware of the happening surrounded by them. A liberated woman thinks on her own, can take decision, has the ability to accept or reject any idea. They hold their own opinion. But when patriarchy operates, to what extent they have been allowed for expression is the next thing to be examined. Talking about the New Women is more appropriate than New Woman. Every individual woman has a different circumstance to respond to. Her portrayal of new women is different from the idea of the Victorian New Woman. In the modern context, they have to endure lots of struggle and suffering. Mohanty's characters are mostly the middle class women, who are affected by
\end{abstract}


DOI: https://doi.org/10.24113/ijellh.v8i1.10381

every small little change in the society. She has also drawn a parallel with the doubly disadvantageous lot of the society, the poor class women. In every situation the characters so dynamically adopt to every situation.

Keywords: Gender Role, New Women, Patriarchy, Individual Suffering, Social Expectations. The stories like "Nabatarnaga”, “Kasturi Mriga O’ Sabuja Aranya”, “Andhakara Ra Chhai”, "Bastraharana", "Madhyantara", "Charitra Hasuchi”, "Pata Dei” have captured the essence of the women characters. Mohanty has encountered the plights of women in her real life and then those characters are being placed in her stories.

"Patadei" has a very strong story because of the assertive woman in the eponymous character Patadei/ Pata. She is fighting for her individual stance without actually caring about what the so called civilized society would think. Basically in our society Indian/Odia, once a woman is married, she then belongs to her in- laws, in no circumstance she can stay with her parents. Pata is actually that new woman who is courageous enough to face the sad reality rather than suppressing the emotional turmoil. Initially she does not express, but then the society she is living in ,does not allow her to do so. She is liberated, does not like the idea to behave as a victim rather prefers to face the reality, however harsh that may be. She rebels, she protests. Soon after her marriage, being dejected by her husband ,she choose to come and stay with her parents. Many people started gossiping :

" pata asila pare kie kahila jwain ra mana manila nahin boli tadi dela, kie kahila sasu sauranka sange kali kalaru gharu tantia maari bidaa kari dele, aau kie kahila sahi lokanka sangare ranga rasa re maatilaaru raati adhhare nia khunta maadi dei gharu bidaa karidele"(Mohanty 136).

My translation: People in the locality started shunning Pata when she came back from her in- laws. Few opine that she could not impress her husband, some others were like, she had a fight with her parents-in-law, and they just got out her from their place. 
DOI: https://doi.org/10.24113/ijellh.v8i1.10381

Others were of the view that she had a loose character, so in the middle of the night she was removed from their house.

In the process, she has been the victim of a gang rape in her village. And then she bears a child. Now as per her understanding the child always belongs to the mother, as she carries it and, the child grows inside her. This theory of course goes against the patriarchal mores but for Pata, she can realize what is legit. But as usual the society would certainly not accept the child whose father's identity is unknown. And ultimately the child is tagged as an illegitimate one.

"All were opinionated, for some she was a lustful woman. After being deserted by her husband no one really appreciates her. On the top of that she is so haugty. God ..she will not be spared. How can she not follow the societal norms? Did not she find poison herself??"(Mohanty 138)

Pata is assertive enough to stick to her position and blame the hegemony. She is justifying her position and uttering the statement that those who are the rapists, all of them are her child's father. Only because a woman's pregnancy or motherhood is visible, that does not give the patriarchal structure a license to question the legitimacy of her child. For her that child is a divine one as she has borne and given birth, so a father's identity she does not consider to legitimize the identity. She shuns the hypocrisy behind. She is the proud mother of that child and that is enough for her. She supports the idea that she does not need the society's approval in the same. She rejects the societal norms completely where women are not treated as human beings rather they are the second sex. Her assertion is loud enough to prove that she is self sufficient. "Patadei" can be considered as a truly liberated woman, having bravery, fearless, above all having the courage to raise her child all alone. She has become the socially estranged person as a woman is not expected to lose her chastity. Here in our society usually the victim becomes the culprit. But Pata ventilates that if she has not done 
DOI: https://doi.org/10.24113/ijellh.v8i1.10381

any wrong why should she shy away." Is there any real man out there who would accept you as his son? Don't cry my child, your mother is always there" (Mohanty 140). So she is one of the courageous new women who prefers to fight her own battle even the society strongly opposes her stance.

In another story "Bastraharana", there are three different phases of stories, and women are portrayed vis a vis their family situation. The second phase has shown Padmini, a working woman who contributes whole heartedly for her husband and his family. A new woman always wants to work, to keep her family happy. But here Padmini is unable to do so. She keeps on enduring everything, but that day her husband crosses every limit when he asks Padmini to be bedded with his boss for some material gain. Here she feels as if she has been reduced to an object and not a human being anymore. Her liberated soul is suffocated. Unbelievable is her hollow existence. The only realization she has is understanding of her position, though helpless yet sympathizes with herself unlike the character Sarasi in the first phase. Whatever contribution she makes that is of no use. Though Sarasi sympathises with herself yet, she is a bondage of marriage and a married woman's sole responsibility is not to defy her husband in any circumstance and has to obey him. Sarasi is unable to disobey but she defies. She is lost somewhere in between the New Woman and the ideal wife. Her forever companion are loneliness, depression, lack of expression. Saswati, in the third phase she too is exploited by the patriarchal norms. The outside world wants her to behave in a certain way, docile, her husband tries to dominate, ridicule her stating how can she be drunk and dance with any man, though that is his usual habit. Such double play in the name of social norms suffocates her. In her words:

My translation: Saswati hanged up the receiver with utmost disguist. Silence prevailing, solitariness as if inviting another devastating war. Her heart desired as if she would set 
DOI: https://doi.org/10.24113/ijellh.v8i1.10381

fire the entire universe. She wishes to laugh out to her satisfaction. She desires to roam around aimlessly...infinite...endless(Mohanty 691).

In symphony with the stories like this where a woman wants to serve the family rather than competing with man, actress Helene Gingold expresses her opinions of the New Woman stating :

The Zeitgeist of the end of the century, and her aim is not to fight, but serve with men in the battle of life. She has found out that there is something for her to live for besides motherhood, pickling and sewing. Pickling and sewing I dismiss with the remark that our great manufacturers do the things much better and far more economically(Gingold,1894).

In addition to the above quote, one more article in the spectator titled " The Professional Women" appeared in 1906 asserts the similar essence,

In the professional woman of today, we see a new development. Two characteristics hitherto inconspicuous have come to the front-independence, and the desire for definite work. By this independence we mean far wider than the mere wish to have her own ways, and by this industry far more active than mere dislike or disapproval of idleness. Like Pata, there is another story where a woman can be assertive for herself as well as other women, has been portrayed. In the story "Durgaa", Moti wants to commit suicide after being dejected from her husband, but Mukti(means freedom) has saved her life. Mohanty has very aptly kept her name so, quite befitting to her character. Here the writer wants to convey that under no circumstance a dejected wife should attempt suicide, attaining wifehood is not the only identity, rather she is an individual having her own stance. A woman necessarily does not need a life for fulfillment, which she has been made believe by the hegemony. Mohanty very well understands the idea of women liberation. Through many of her stories she has tried to voice against exploitation, inequality. Stories like, "Akahani", "Swapna 
DOI: https://doi.org/10.24113/ijellh.v8i1.10381

Agami Prabhata ra", "Udayana", "Chalanti", "Maruchhaya" deal with the economically weaker section and women, the writer has tried to pave a way for these women. Her portrayal of woman is not hopeless and helpless rather a protest. The writer cannot stand hypocrisy. The social norms should be meant for both man and woman . Different set of parameters actually create a scope of inequality for both man and woman. An "Ideal" state or individuality should be associated with both of them. A woman alone should not be expected to perform the task or desired roles, just to prove herself worthy of the society.

The story "Freezed" captures a peculiar state. Being dejected by her husband, Alaka becomes mentally and emotionally unstable. She is unable to revolt, because she understands the fact that the society she lives in glorifies such traits in husbands, so there is hardly any scope of her questioning that. Her husband is merely a part of that acculturation. But she wants to be liberated, free and then Alaka goes to Malini. Malini is very different as if she is a rebel, having relationship with many men but whenever comes to her husband Bibhuti, she becomes quite loyal and honest. Bibhuti is the person who does not hesitate to ask his wife to bed with many men immediately after their marriage. So basically Alaka and Malini are kept on the same plane and footing, there is hardly any difference in their position with regard to relationship. Here the two women are unable to take any step against what they face, the only resort is the realization of their position, which gives them immense dissatisfaction. Mohanty has tried to explain that irrespective of the caste and class, a woman's position remains the same, they share the similar problem, almost the experience remains same. A woman's space and scope becomes limited within the ambit of patriarchy. She may be the wife of an extremely rich man, or a working woman, and wife of a middle class man, or a poor uneducated housewife-they experience life in a similar way. In the early olden days mostly the society was matriarchal. Their was a gradual change, a complete shift in the scenario. 
DOI: https://doi.org/10.24113/ijellh.v8i1.10381

Another aspect of Mohanty's stories centres around the idea of a woman should fight for another woman, rather than fighting with another woman. But unfortunately the later is more true. Mostly two stories have reflected on this idea of empathy, for a woman by a woman. When a woman is liberated, she can be termed as a new woman, necessarily new woman posses the quality like empathy not jealousy and envy- usually associated with prototype woman. Stories like "Arghya" and "Adhikara" capture those new women. "Adhikara" is all about a poor woman, though she begs to feed herself, yet her empathy is way better than any educated individual in the modern society. She is trying to protect the honor of another woman. In the story "Shikha", the lead female character Nirmala has become a Sikha means "Flame", who is ready to fight against this social malady. She is neither suppressed nor submissive, she raises her voice against the society. She has been exploited and tortured by her in laws, her husband -only because she did not fulfill the dowry demand of her in laws. Unlike most of the married women in the society, she has decided to raise her voice against the system rather than fleeing or committing suicide. She is burning from within and finally with that flame or fire, she tries to burn her -in laws house. In Mohanty's words:

Out of anger and pain, as if she shed fire ? So all girls' death would be destined this way?..Does she deserve only sympathy..? No ways..I will not allow..she observed..it was all dark in the night and quiet and calm..she opened the door and got out. She would not allow the same drudgery further..she would set fire everywhere. She would destroy the system and the makers of such system(Singh 144).

Here Shikha is actually the mouthpiece of the writer, who is trying to voice out against the social evil, dowry. While searching for a way for the liberated woman, the writer has projected the woman with a voice and not a dumb. As per her understanding, if woman enjoys freedom, liberty in every sense, then only there is a possibility of an ideal society, a 
DOI: https://doi.org/10.24113/ijellh.v8i1.10381

progressive one. For the writer, a woman needs to recognize her potential as well as what she deserves, she only knows her duties, but hardly most of the time she is aware of her rights. If a woman is a creator, she can destroy as well.

In "Nai", Anubha is becoming the new woman gradually, her story is about innocence to experience. Initially she is too young and naïve to understand the double play of patriarchy. Eventually she becomes more aware of her existence, individual stance. Without hesitation she expresses her disguist. She has the guts to question the society regarding the different treatment she gets. Woman is not a doll in the hands of the society and patriarchy. Ms. Mohanty writes: Lugaa kaani re luha pochu pochu Anubha Kahila-' Nahin Re Bishu. Au Daribini . Sitar a gaouraba nei jali jaichhi sinaa, hele ee jalibaare saanti kahin.? Ebe se nia j mote jaali samatanku jaali basilaani..(Mohanty 490).

My translation: While wiping her tears, Aubha utters " No Bishu. No more I would be scared of. It was just due to inspiration drawn by Sita, but such sacrifice is futile, worthless. No peace left in my life. Now that fire has set in to burn all along with me.

She adds:

ha han jaalu..jali jau Bishu. Saara pruthibi tah mo bhali Stree loka nka aakhi nia re jaali jau. Mu jibi - jai samastinki pacharibi- stree lokankara kana jibana nahin, banchibara adhikara nahin, se kana sabu din aemiti purusha jaati ra, samaja ra , dharabandha niyam ra , mana gadha kahani katha ra khelana kandhei heithiba? Mu jibi, pacharibi..arey Bishu..kouthi jaadi ishwara thaanti, dharma, nyaya ei sansar re thaee, tebe semaane mote bujhei diantu..Stree loka kan anuhe..han haan mu pacharibi..hey akasha...hey patala..(Mohanty 490).

My translation: Yes Bishu. The entire universe should be burnt out of tears shed by women like me. I will definitely go and ask everyone- does not a woman deserve to live, is she born to suffer, to be trampled by patriarchy and society, set by the 
DOI: https://doi.org/10.24113/ijellh.v8i1.10381

regulations, would only remain a doll in the name of destiny? I will certainly go, I will ask..Arey Bishu..if at all God exists...if there is any religion, civilization..then they should make me understand ...does not she carry any existence?

This dimension in any woman takes her much longer to realize, recognize her existence and to value it. As she is being raised in a way that prepares her for endurance, compromising for her family and belittling herself. The voice is of the new woman, who can protest too. She adds more:

mo rakta ku, mansha ku soshi khauthila, ebe mu kahaku darena, kahaku khatir karena, mu jibi..jibi...ekela jibi...pacharibi stree loka hoi janmibaare ete dosha kahinki..pacharibi maa hoi na paribara mora aparadh kana....pacharibi..swami stree bedi re baha hoi, swami mane stree manaku kete dina emiti maati kandhei kari khelibe?/ mu chhadibini. Na kahaku mu darena.. arey Bishu/ mu kana manisha nuhan?manisha ku mu kahinki daribi re??"(Mohanty 490) My translation: All have been exploiting me. Now I am scared of no one, I don't care either, I will go...alone will go..I will ask..what's wrong in being born a woman? What is wrong in not being able to attain motherhood? I will ask...does the nuptial knot gives man a license to treat his wife as a doll? I will not spare. I am not scared of anyone. Arey Bishu..am I not a human being? Then why should I be afraid of human beings? She has lot many queries and dissatisfaction as a woman is still considered as the second sex. Woman is not a doll in the hands of the society and patriarchy. In an interview with Dr. Induprava Samal, she has asserted the idea that she always talks about humanism and of course the call of feminism is included in the same. And this very understanding can definitely lead towards a healthy society. ( Samal,2014)

There are other female characters too, created by Mohanty, who have been exploited, raped, tortured, in spite of such penury they are not really lost or wounded. Again they have 
DOI: https://doi.org/10.24113/ijellh.v8i1.10381

shaped themselves to fight. They have accepted the struggle, difficulties as a part and parcel of life, which can be a pause but not a full stop. A woman has the potential to bring about lot many changes and those changes have taken place. The story “ Kasturi Mriga O' Sabuja Aranya" captures how Neelambari at last, expresses herself, she understands that monetary benefit is not all about happiness in conjugal life. She proves that Indrajit, her husband is wrong in concluding that she is the most fortunate woman ever. In her words:" na na mu kholibini. Kana tume kariba kara. Tamara sabu katha mu ajibana mani asichhi. Suna panjuri re sua ku amruta dei rakhile bi se posa manenaa boli tumara mane rakhiba uchhit”(Mohanty 136).

My translation: No no.. I will not open the door. Whatever you wish you can do. I have been listening to you till date. You should remember that you cannot tame a bird even if you confine her in a golden cage.

For her happiness is not all about accepting the bondage of a rich and affluent husband where there is no value of a wife's voice. So at last she is becoming quite assertive and vocal.

"Katha Tiye Kahun" deals with two types of woman one, who surrenders herself in front of her husband and becomes a dependent one. But on the other, Surabhi has to take a job to earn bread and butter and to feed her family. But the society does not approve of her complete independence which certainly makes her suffocated. Surabhi has the guts to refuse her boss, when she does not like the proposal. In the presence of the entire office staff, she bangs on him. She has herself respect and she understand the demarcating lines between her colleagues and herself. A new woman has to struggle where as Mallika, who is the creation of Patriarchy is really not bothered as she is reliant on her established engineer husband. She prefers to become the doll and lead a comfortable life where there is no struggle. Surabhi has the burden of entire family to take care of. Unfortunately and ultimately she has to lose her job because of her righteousness. A woman has to struggle always. 
DOI: https://doi.org/10.24113/ijellh.v8i1.10381

"Chitthi, Chitthi, Chitthi”, tells about three women friends, it is about humiliation which a woman faces, the drudgery in her life. The first woman of the story can continue with her studies even after getting married at a very early age. Then she is employed and takes care of the entire family. The second woman in the story holds the idea of an independent woman. She gets married to a rich man, but eventually realizes that he is a drunkard. On the other hand she is childless, so as usual there is a question mark regarding her acceptance in the family. As per the patriarchal structure, a woman gets fulfillment only after attaining wifehood and motherhood. The third woman in the story becomes widow within a very short span of her marriage. Her struggle reaches culmination when after her husband's death, his friends wanted to be physical with her. As if now she is the most available commodity. She is being crushed with the false social prestige. Here all of them are striving for getting their liberated self, individual stance.

"Maati" is another story where the protagonist has actually showcased her independent thought and unperturbed by the social structure, a woman driven by logic and her instinct. This facet of the Indian girl, a new woman, has her courage to stick to her decision is truly commendable. She belongs to a Hindu family and in love with a Muslim man and marries him too against all sorts of social odds. But as expected she has to undergo a roller coaster ride and endurance. A new woman can actually settle with right or wrong.

"Swapna Sundari" projects composure in a woman which helps her to lead a blissful conjugal life after so much of difficulties in the initial phase of her marriage. Sanjeet is a higher official, only for getting a huge amount of dowry he gets married to Geeta, who is not so beautiful. But she is sensible and patient enough, and quite aware of how to deal with real life problems. At last a remarkable and drastic change is noticed in her husband's attitude. Both of them are now successful couple. Wollstonecraft supports this idea, 
DOI: https://doi.org/10.24113/ijellh.v8i1.10381

I speak of the improvement and emancipation of the whole sex, for I know that the behavior of a few women, who by accident, or following a strange bout of nature, have acquired a portion of knowledge superior to that of the rest of their sex, has often been overbearing; but there have been instances of women who, attaining knowledge, have not discarded modesty, nor have they always pedantically appeared to despise the ignorance which they labored to disperse in their own minds(Wollstonecraft,1996). Formal education does not really coincide with a deeper understanding about life. A perfect example can be seen in the story "Kapidhwaja". Here an uneducated woman exercises her independent thinking. A daily laborer dies when the labor union is following a hunger strike for their demand fulfillment. Certainly, the other co workers want to sympathize with the widow of that worker, instead she asks the rest of the people to continue with the strike. It reflects solidarity in a woman, who can think for the entire fraternity, rather than brooding over the past. Neither she is self centered, nor the weaker section of the society.

Another woman Tilottama in the story "Tilottama" has the courage to speak her heart out. She is a brilliant and studious girl. She wants to pursue higher studies, but her not-soeducated brothers want her to get married. She has protested about her rights that she would continue with studies as she too deserves an equal share in her father's property, unlike typical woman who would be desiring of getting equal share yet become hesitant due to the latent social force. It is actually the voice of an empowered women. Gingold's words can be quite befitting here:

She can work in nearly all departments as well as man himself, and instead of unsexing her, this has broadened her sympathies and lessened infinitely her unlovely characteristics of pettiness and spite. The New Woman has been brought up with brothers, has joined in their studies and games, and through it has become bright in intellect, strong of limb, and beautiful to look upon (Gingold,1894). 
DOI: https://doi.org/10.24113/ijellh.v8i1.10381

"Drushyantara" projects how in the current scenario a widow survives in a workplace with the male colleagues. When her husband was alive she had to experience her life differently, now when he is not alive, she is undergoing a different sort of affair. She can clearly differentiate the kind of treatment she deserves and what she receives. Obviously, it creates much of difficulties for a woman to survive under such circumstances, where it becomes a dream for her to expect just and human treatment. In a very subtle way, Mohanty has tried to portray the "New Woman", her desire, her understanding. In our social structure both men and women are equally helpless, but comparatively a woman's position is more vulnerable. Social, familial, professional, psychological: from every aspect she becomes doubly disadvantageous. With enlightenment and empowerment she realizes what she can achieve through endurance. Most of Mohanty's stories have captured the essence of the woman one can encounter in our day to day life, few of them realize where as few do not. Empowering one's mind requires courage, patience, endurance, discipline, consciousness and promptness to handle the situations."Padmatola" talks about Maneka who is courageous enough to voice against colonial set up, means the hegemonic structure. She rebels in a furious and just way when the police indicates in a vulgar manner. She becomes enraged to the extent of killing those. Nothing can scare her, once she is convinced of her righteousness.

Sanjukta is a working woman in "Jau", due to some office politics she is being raped by few anti socials. She becomes more broke when her husband, a typical misogynist, makes her responsible for what all wrong has happened with her. Even if she has dedicated her whole life for her family, yet it is in vain. She is no more a rubber ballon, transient in nature and does not hold any worth. "Bhaunri" has another woman Anjana, understanding her position in the family. She receives rejection and dejection even after taking care of the entire household and each member of the family. She desires for freedom which would enable her more to strike a fine balance between the home and the world, family and work outside. 
DOI: https://doi.org/10.24113/ijellh.v8i1.10381

"Debadalana" projects a woman Sumati, her agenda shows an enlightened mind. She is educated, providing education to the orphans and trying to promote adult education. in addition to that she has tried to uplift the lower caste of the society , "Harijan" caste. With her venture, they can be included in the mainstream of the society. At last she goes along with the Harijans inside the Shiva temple. She herself belongs to the lower strata, but at last a higher caste man, Harish, helps her doing so for the betterment of the society. Finally their marriage is solemnized, Sumati is truly empowered in spite of her caste and gender, she is a liberated soul. Lyndell argues that education and equality for women will give them a deeper understanding of love and life, as they can now enjoy its full benefits. All of society will benefit from women's equality. ( Schreiner,2008)

"Kalpana" has a reflection of another independent girl having determination to find a match for herself. The criteria being that her marriage would not include any dowry. She would marry such a man who does not demand dowry. As she is in love with a professor and who would marry her without any dowry, she has decided to marry him, only him. Kalpana is quite assertive in her approach. In most of the Indian societies, the day a girl is born , her family is really worried of her marriage, only because an arrangement for a huge amount of money becomes quite difficult in her poor parents' part. It is certainly a social evil, and girls need to aware of the same for the complete uprooting of the same problem, like Kalpana who is another new woman in Mohanty's creation.

"Chameli Ra Cha" has the story of a poor old woman, after being deserted by her husband, she comes down to the town for her survival. A tea stall becomes her only source to earn her livelihood. She keeps herself engaged in her business. When she gets to know about her husband's illness, she rushes to his place to nurture him. Chameli is illiterate, yet she understands her responsibility as a wife as well, as and when required, she does not hesitate 
DOI: https://doi.org/10.24113/ijellh.v8i1.10381

to become financially independent, so that she can feed her family. This story certainly brings a kind of awakening in the minds of today's woman.

Mohanty has successfully highlighted the consciousness of women, there is the sign of interrogation and questioning the unstructured society. Because the same society does not provide any kind of scope and avenue for women to become emotionally, economically or intellectually independent rather it creates abhorrence and obstructions. The patriarchal forces become so instrumental, it tries to check every possible way or mode of development in case of women, her respect, freedom and autonomy is suppressed. Her articulation and expression does not get a place. The portrayal is about the modern new woman and not the Victorian idea of New Woman who was understood to be the woman who disobeyed her husband, basically her portrayal was negative in nature. These new women understand striking a balance between their role, responsibilities and rights. 
DOI: $\underline{\text { https://doi.org/10.24113/ijellh.v8i1.10381 }}$

Works Cited

Gingold, Helen. “ The New Woman: A Vindication.” The Pall Mall Gazette, 28 September 1894, issue 92:09.

Mohanty, Binapani. Galpasamagra. Cuttack: Bidyapuri, 2008.

Mohanty, Binapani. Patadei: A Collection of Short Stories.Cuttack: Bidyapuri,2008.

Samal ,Induprava. Binapani Mohanty nka Galpare Jibanadristhi. Bhubaneswar: Swastik, 2014.

Schreiner, Olive. The Story of an African Farm.Oxford: Oxford University Press, 2008.

Singh, Bijayananda. Ed. Binapani Mohantynka Srestha Galpa(Odia Original).New Delhi: NBT,2014.

“The Professional Woman,” The Spectator,17 February ,1906.

Wollstonecraft, Mary. A Vindication of the Rights of Women. Mineola: Dover, 1996. 